\title{
Pengaruh Zat Besi (Tablet Fe) Terhadap Berat Badan Lahir Pada Ibu Bersalin Normal
}

\author{
Zulliati $^{1}$, Nita Hestiyana ${ }^{2}$ \\ ${ }^{1,2}$ Universitas Sari Mulia \\ correspondence author: Telpon: 085252756399. \\ E-mail: Zulliatiibaq@gmail.com
}

DOI: https://doi.org/10.33859/dksm.v10i1.401

\begin{abstract}
ABSTRAK
Latar Belakang: Anemia dalam kehamilan mempengaruhi lebih dari 500 juta wanita dalam masa kehamilan, yang nantinya dapat dikaitkan dengan gangguan pada ibu dan bayi. Suplementasi zat besi selama masa kehamilan diberikan secara terus menerus adalah alternatif yang menarik. Anemia sering terjadi akibat defisiensi zat besi dikarenakan pada ibu hamil terjadi peningkatan kebutuhan zat besi dua kali lipat akibat peningkatan volume darah tanpa ekspansi volume plasma, untuk memenuhi kebutuhan ibu (mencegah kehilangan darah pada saat melahirkan) dan pertumbuhan janin.

Tujuan: Artikel ilmiah ini mencoba menelaah berdasarka studi literature hasil penelitian mengenai penggunaan tablet zat besi terhadap peningkatan berat badan lahir bayi.

Metode: Studi ini merupakan tinjauan literatur yang dilakukan dari tiga jurnal penelitian yang dilakukan di Viet Nam dan Spayol dan systematic review dari beberapa Randomized Controlled Trial yang dilakukan di cluster dan community

Hasil: Beberapa penelitian menyebutkan terdapat korelasi yang erat antara anemia pada saat kehamilan dengan kematian janin, abortus, cacat bawaan, berat bayi lahir rendah, cadangan zat besi yang berkurang pada anak atau anak lahir dalam keadaan anemia gizi.

Kesimpulan: Pemberian zat besi selama kehamilan selama ini diyakini dapat mengatasi anemia dalam kehamilan untuk menghindari persalinan prematur dan perdarahan pada saat persalinan,
\end{abstract}

Kata kunci :Berat badan lahir, zat besi 


\section{Influence of Iron (Tablet Fe) on Weight Loss in Normal Maternity}

\section{ABSTRACT}

Background: Anemia in pregnancy affects more than 500 million women during pregnancy, which can later be associated with disorders of the mother and baby. Iron supplementation during pregnancy is given continuously is an attractive alternative. Anemia often occurs due to iron deficiency because in pregnant women there is a doubling of iron demand due to increased blood volume without plasma volume expansion, to meet the needs of the mother (preventing blood loss during childbirth) and fetal growth.

Purpose: This scientific article tries to examine the literature based on the results of research on the use of iron tablets to increase infant birth weight.

Methods: This study is a literature review conducted from three research journals conducted in Viet Nam and Spain and a systematic review of several Randomized Control Trials conducted in clusters and communities.

Results: Several studies suggest that there is a close correlation between anemia during pregnancy and fetal death. , abortion, congenital defects, low birth weight, reduced iron reserves in children or children born in a state of nutritional anemia.

Conclusion: The administration of iron during pregnancy is believed to be able to overcome anemia in pregnancy to avoid premature labor and bleeding during labor,

Keywords: Birth weight, iron

\section{PENDAHULUAN}

Ibu hamil merupakan salah satu kelompok rawan kekurangan gizi, karena terjadi peningkatan kebutuhan gizi untuk memenuhi kebutuhan ibu dan janin yang dikandung. Anemia dalam kehamilan mempengaruhi lebih dari 500 juta wanita dalam masa kehamilan, yang nantinya dapat dikaitkan dengan gangguan pada ibu dan bayi, suplementasi zat besi selama masa kehamilan diberikan secara terus menerus adalah alternatif yang menarik. Pola makan yang salah pada ibu hamil membawa dampak terhadap terjadinya gangguan gizi antara lain anemia, peningkatan berat badan yang kurang pada ibu hamil dan gangguan pertumbuhan janin. ${ }^{1}$ Salah satu masalah gizi yang banyak terjadi pada ibu hamil adalah anemia gizi, yang merupakan masalah gizi mikro terbesar dan tersulit diatasi di seluruh dunia. World Health Organization (WHO) melaporkan bahwa terdapat $52 \%$ ibu hamil mengalami anemia di 
negara berkembang. Di Indonesia (Susenas dan Survei Depkes-Unicef) dilaporkan bahwa dari sekitar 4 juta ibu hamil, separuhnya mengalami anemia gizi dan satu juta lainnya mengalami kekurangan energi kronis.

Peningkatan morbiditas dan mortalitas ibu, serta tingkat kelahiran prematur yang tinggi dan berat badan lahir rendah, yang mengurangi kelangsungan hidup bayi, dengan konsekuensi jangka panjang yang potensial untuk pertumbuhan dan perkembangan anak. Hal yang sudah dilakukan selama ini adalah dengan pemberian zat besi pada ibu hamil dimulai trimester kedua, diharapkan pada saat ini ibu sudah dapat beradaptasi dengan kehamilannya dan keluhan yang lazim terjadi pada awal kehamilan sudah berkurang. Meski pelaksanaannya sudah dapat dikatakan sukses namun ketidakpatuhan dan kesulitan dalam mengakses zat besi dikalangan masyarakat pedalaman yang sering dilakukan ibu merupakan kendala utama.

Kekurangan zat besi banyak diderita oleh ibu hamil, menyusui, dan perempuan usia subur. Perempuan usia subur mempunyai siklus tubuh yang berbeda dengan laki-laki, anak, dan balita sebab mereka harus mengalami haid, hamil, melahirkan, dan menyusui. Oleh karena itu kebutuhan zat besi (Fe) relatif lebih tinggi. Defisiensi zat besi pada ibu dalam masa kehamilan terjadi akibat peningkatan kebutuhan zat besi menjadi dua kali lipat yang disebabkan peningkatan volume darah tanpa ekspansi, volume plasma untuk memenuhi kebutuhan ibu dan pertumbuhan janin. Sangat memprihatinkan diestimasi dibawah 50\% ibu tidak mempunyai cadangan zat besi yang cukup selama kehamilan, sehingga resiko defisiensi zat besi meningkat bersama dengan kehamilan. ${ }^{2}$

\section{METODE}

Studi ini merupakan Literatur Review yang menggali lebih banyak informasi mengenai pengaruh zat besi terhadap peningkatan berat janin, yang akan berpengaruh pada berat lahir. Sumber untuk melakukan tinjauan literatur ini meliputi pencarian sistematis database terkomputerisasi (Cochcrane Collaboration, Pubmed, Midwifery Journal, Google Cendikia). Dalam kajian ini digunakan 
Dinamika Kesehatan Jurnal Kebidanan dan Keperawatan Vol 10 No. 1 Juli 2019 ( ISSN: 2086-3454 EISSN: 2549-4058) url: http://ojs.dinamikakesehatan.unism.ac.id DOI : https://doi.org/10.33859/dksm.v10i1

Pengaruh Zat Besi (Tablet Fe) Terhadap Berat Badan Lahir Pada Ibu Bersalin Normal

beberapa penelitian yang dilakukan dengan 1

teknik Randomized Control Trial yang

dilakukan di Rural, Viet Nam, 2 penelitian

yang lain juga dilakukan di Cleveland, Ohio

Amerika Serikat, 3 dan double blind randomised community trial yang dilakukan di

Nepal dan 1buku Phd-Hay-oleh Gry Hay.

Penulisan artikel ilmiah ini menggunakan

penulisan daftar pustaka Vancouver.

\section{HASIL}

Perkembangan pengetahuan dan pemantauan ditunjukan pada masa bayi dan masa anak-anak yang dipengaruhi dari masa janin didalam kandungan. Kekurangan zat besi yang tinggi dapat menghambat kualitas dari perkembangan kognitif pada janin. Pengaturan konsumsi zat besi pada ibu yang memiliki cadangan besi juga harus mendapatkan perhatian karena hemokonsentrasi dari potensi tingkat ferintin yang rendah pada masa kehamilan, hal ini dapat meningkatkan resiko stress oksidatif yang dapat memperburuk kehamilan. Kadar zat besi pada usus yang tinggi juga dapat meningkatkan resiko dalam masa kehamilan serta dapat menyebabkan berkurangnya penyerapan mineral penting lainnya. $^{2}$

Zat besi adalah mineral yang dibutuhkan untuk membentuk sel darah merah (hemoglobin), mineral ini berperan sebagai komponen untuk membentuk mioglobin (protein yang membawa oksigen ke otot), kolagen (protein yang terdapat ditulang, tulang rawan dan jaringan penyambung serta enzim. ${ }^{4}$

Kebutuhan zat besi selama hamil yaitu rata-rata $800 \mathrm{mg}-1040 \mathrm{mg}, 300 \mathrm{mg}$ diperlukan untuk pertumbuhan janin. pada trimester kedua hingga ketiga volume darah dalam tubuh ibu akan meningkat sampai $35 \%$. Ekuivalen dengan $450 \mathrm{mg}$ zat besi untuk memproduksi sel-sel darah merah, sel darah merah harus mengangkut oksigen lebih banyak untuk janin.

Sumber zat besi adalah makanan hewani (daging, ayam dan ikan) sumber lainnya yaitu telur, sereal, kacang-kacangan, sayuran hijau dan beberapa jenis buah. Pada umumnya besi di dalam daging, ayam dan ikan mempunyai ketersediaan biologik tinggi sedangkan pada yang lain ketersediaan biologiknya sedang. 
Dinamika Kesehatan Jurnal Kebidanan dan Keperawatan Vol 10 No. 1 Juli 2019 ( ISSN: 2086-3454 EISSN: 2549-4058) url: http://ojs.dinamikakesehatan.unism.ac.id DOI : https://doi.org/10.33859/dksm.v10i1

Pengaruh Zat Besi (Tablet Fe) Terhadap Berat Badan Lahir Pada Ibu Bersalin Normal

Pemberian suplemen zat besi perlakukan dan placebo pada kelompok

disesuaikan dengan usia kehamilan atau

kebutuhan zat besi tiap trimester yaitu:

1. Trimester I kebutuhan zat besi kurang lebih

$1 \mathrm{mg}$ per hari ditambah $30-40 \mathrm{mg}$ untuk kebutuhan janin dan sel darah merah.

2. Trimester II kebutuhan zat besi kurang lebih 5 mg per hari ditambah kebutuhan sel darah merah dan janin $300 \mathrm{mg}$.

3. Trimester III kebutuhan zat besi $5 \mathrm{mg}$ per hari ditambah kebutuhan sel darah merah dan janin $223 \mathrm{mg}$.

Selama masa kehamilan zat besi sangat berperan penting dalam perkembangan berat janin. Tranformasi mineral dan zat makanan lain sangat berpengaruh terhadap ketersediaan hemoglobin didalam sel darah merah, yang akan berfungsi mengirimkan oksigen, mineral dan zat makanan sampai ke janin.

Penelitian yang dilakukan di Cleveland Ohio, Amerika Serikat yang dilakukan pada 513 ibu hamil dengan usia kehamilan diatas 20 minggu, pemantauan dilakukan sampai usia keham 38 minggu dan saat bayi lahir. Penelitian ini memberikan perlakuan dengan memberikan kapsul zat besi pada kelompok kontrol, yang kemudian dinilai peningkatan berat janin dengan menggunakan USG selama masa kehamilan dan setelah lahir dengan pengukuran antropometri bayi. Hasil penelitian ini menunjukkan kelompok yang diberikan perlakuan dengan zat besi signifikan lebih kecil kemungkinann untuk memiliki bayi dengan berat lahir rendah dan lahir prematur dibandingkan dengan kelompok kontrol yang hanya mendapatkan plasebo, dengan nilai $p=0,004(p=0.05) .^{2}$

Penelitian lain yang dilakukan di Vietnam, menunjukkan bahwa kelompok yang mendapatkan asupan zat besi harian memiliki angka kelahiran prematur dan berat lahir rendah lebih sedikit dibandingkan kelompok yang mendapatkan suplemen besi 2 kali seminggu. ${ }^{1}$ Hal ini juga terdapat pada penelitian lain yang dilakukan di Nepal mendapatkan bahwa suplemen asam folat dan zat besi selama masa kehamilan mengurangi resiko melahirkan bayi dengan berat lahir rendah dan kejadian lahir premature. ${ }^{3}$

Seperti yang tercantum dalam jurnal yang diterbitkan oleh Paediatric and Perinatal 
Dinamika Kesehatan Jurnal Kebidanan dan Keperawatan Vol 10 No. 1 Juli 2019 ( ISSN: 2086-3454 EISSN: 2549-4058)

url: http://ojs.dinamikakesehatan.unism.ac.id DOI : https://doi.org/10.33859/dksm.v10i1

Pengaruh Zat Besi (Tablet Fe) Terhadap Berat Badan Lahir Pada Ibu Bersalin Normal

Epidemiology dengan judul Nutrition

Education and counselling Privided during

pregnancy: effect on maternal, neonatal and

child Health Outcome. WHO

merekomendasikan suplemen zat besi yang

dikonsumsi oleh wanita hamil adalah sebesar

$60 \mathrm{mg}$ per hari selama lebih dari 90 hari masa

kehamilannya. $^{5}$ Dalam jurnal tersebut

menyampaikan bahwa konseling gizi dan

makanan yang mengandung zat besi yang

tinggi selama kehamilan dapat mengurangi

resiko anemia, abortus, berat lahir rendah dan

meningkatkan kekebalan tubuh bayi.

\section{Simpulan}

Intervensi yang diberikan selama masa

kehamilan dengan pemberian zat besi

dibutuhkan. Zat besi yang merupakan

komponen pembentuk sel darah merah

merupakan bagian dari pembentuk

hemoglobin yang sangat berpengaruh terhadap

suplai oksigen, mineral dan zat gizi lain yang

dialirkan melalui plasenta ke janin. Secara

langsung dapat mempengaruhi berat janin dan

berat lahir. Bukti yang kuat dari beberapa

penelitian menunjukkan bahwa pemberian zat besi selama kehamilan dapat mempengaruhi berat lahir bayi, dan mengurangi kelahiran prematur dan berat lahir rendah.

\section{Daftar Pustaka}

Haniah S, Ha TT, Simpson Ja, Casey GS, Khuong NC, Thoang DD, dkk. The effect of intermitten antenatal iron supplementation on maternal and infant outcome in Rural Viet Nam. PlosMed.18 juni 2013;10(6):1-15

Cogswell ME, Parwanta I, Ickes L, Yip R, Brittenham GM. Iron suplementation during pregnancy anemia and birth weight. American Society for Clinical Nutrition. 2003;hlm 1-9

Christian P, Khatry SK, Katz J, Pradhan EK, Leclerg SG, Shrestha SR, dkk. Effect of alternative maternal micronutrient supplements on low birth weight in Rural Nepal. BMJ. 15 Maret 2013; Vol. 326:hlm 1-6

Hay Gry. Iron, folat and cobalamin status in infants and toddlers a longitudinal study of Norwegian children 0-2 years. Departement of Nutrition Institut of Basic Medical Sciences Faculty of Mediciene Univ. of Oslo.2015

Girard A, Olude O. Nutrition education and counselling provided during pregnancy effect on maternal, neonatal and child health outcome. Pediatric and perinatal epidemiology. 2012.112(1):191-04 